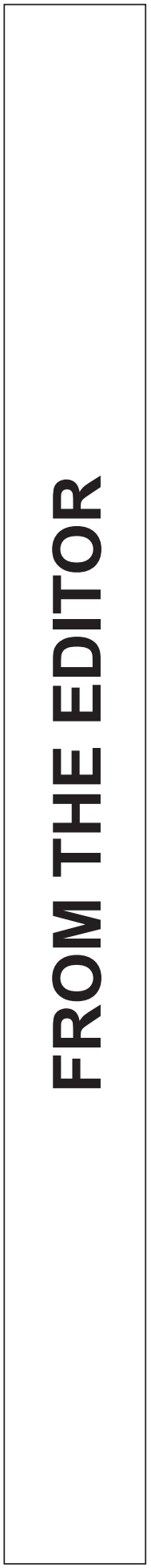



DOI : $10.14746 /$ ps.2018.1.1

\section{THE MILITARY STATUS QUO ON THE EURASIAN CHESSBOARD}

One of the more popular bon mots from Stanisław Wyspiański's drama The Wedding is the question: "So, what's new in politics, sir? Haven't the Chinese answered yet?" (Wyspiański, 2012: 23), which can be interpreted as both an allusion to the political situation at the time ${ }^{1}$ and an anticipation of developments in the $21^{\text {st }}$ century.

Today, the same question pertains to China, as well as to a much more expansive territory which Zbigniew Brzeziński named Eurasia (the Eurasian Chessboard). More than twenty years ago, he tackled this issue for the first time in his interesting and inspiring book The Grand Chessboard. Brzeziński argued that Eurasia is the largest continent in the world, stretching from Lisbon to Vladivostok, and that its exceptional importance results from its political, economic, military and demographic potential. "About 75 percent of the world's people live in Eurasia, and most of the world's physical wealth is there as well, both in its enterprises and underneath its soil. Eurasia accounts for about 60 percent of the world's GNP and about three-fourths of the world's known energy resources. [...] Eurasia is also the location of most of the world's politically assertive and dynamic states. After the United States, the next six largest economies and the next six biggest spenders on military weaponry are located in Eurasia. All but one of the world's overt nuclear powers [...] are located in Eurasia" (Brzezinski, 1997: 31).

Brzeziński concludes that all of this makes Eurasia a grand chessboard on which players fight for global hegemony. All the countries than could potentially pose a threat to US economic and political primacy are located there.

This claim was made in the $20^{\text {th }}$ century, which raises doubts as to the accuracy of this diagnosis at present. Does the US continue to dominate in the word? What is US potential compared to its major competitors? Does the Eurasian chessboard continue to play such a crucial role in the world today?

An overview of events occurring on the international arena, including Eurasia, demonstrates more or less significant shifts in the ranking of states' importance and power. These shifts are the outcome of the internal situations in the respective countries and of global evolutionary changes. They can be examined applying different criteria and research tools. There are six main elements of state power investigated for this purpose, namely:

1) military power including, among other things, the size of military forces, the level of technology available to them, technical and organizational capacity, army training and weaponry, and the level of strategic thinking, etc.

\footnotetext{
1 The Wedding was first presented in 1901.
} 
2) geographical factors related to the state's size and location, its climate, topography, natural resources, sources of energy and the level of agricultural output;

3) demographic factors, such as the population, population density, social structure (age, education, sex, etc.);

4) economic potential connected with the development of trade, the ability to provide adequate living standards to the population, the range and efficiency of the transportation system, and so on;

5) the political system, its structure and how it makes use of the resources it has at its disposal;

6) international authority and position, including efficient diplomacy and the level of support that the state enjoys on the international arena (Łoś, 2017: 47-48).

Given the comprehensive and complex character of these issues, this brief introduction addresses only the analysis of contemporary military power and compares the potential of the most powerful actors. The first model applied here is the extensive and exhaustive calculation system of the Global Firepower Index (Military, 2018).

It covers over 120 states $^{2}$ and as many as 55 different factors which reflect their respective military power, such as population (including the number of people fit for service and in reserve), the potential of the air force and navy, the number of tanks and heavy artillery, the size of the infantry, military expenditure, currency reserves, production of crude oil, the length of roads and rail tracks, and many others. Significantly, the Power Index does not take into account weapons of mass destruction, including nuclear weapons. ${ }^{3}$

The maximum military power indicator for states amounts to 0.00 in the system adopted by the Power Index. The higher the indicator, the lower the potential. According to the Power Index, the following states were the top ten military powers in 2015 and 2018.

Table 1

Global Firepower Index 2015 and 2018 - global top ten military powers in terms of their respective ranking and index calculated

\begin{tabular}{||l|c|c|c|c||}
\hline \multicolumn{1}{|c|}{ Country } & $\begin{array}{c}\text { Country rank } \\
\mathbf{2 0 1 5}\end{array}$ & Index 2015 & $\begin{array}{c}\text { Country rank } \\
\mathbf{2 0 1 8}\end{array}$ & Index 2018 \\
\hline USA & 1 & 0.1661 & 1 & 0.0818 \\
\hline Russia & 2 & 0.1865 & 2 & 0.0841 \\
\hline China & 3 & 0.2315 & 3 & 0.0852 \\
\hline India & 4 & 0.2695 & 4 & 0.1417 \\
\hline United Kingdom & 5 & 0.2743 & 6 & 0.1917 \\
\hline France & 6 & 0.3065 & 5 & 0.1869 \\
\hline South Korea & 7 & 0.3098 & 7 & 0.2001 \\
\hline Germany & 8 & 0.3505 & 10 & 0.2461 \\
\hline Japan & 9 & 0.3838 & 8 & 0.2107 \\
\hline Turkey & 10 & 0.4335 & 9 & 0.2216 \\
\hline
\end{tabular}

Source: Own elaboration on the basis of Global Firepower Index 2015, Global Firepower Index 2018, Military Strength Ranking, https://www.globalfirepower.com (1.07.2018).

${ }^{2} 126$ states were included in the 2015 edition while 136 states were taken into consideration in 2018.

${ }^{3}$ For more on research methodology see: Global Firepower Index (Military, 2018). 
The comparison of the results obtained by the Global Firepower Index for 2015 and 2018 reveals a few interesting facts. In both cases, the so-called Grand Three (the US, Russia and China) have a clear lead over the remaining most powerful countries. While all ten analyzed countries increased their military potential, some of them moved up or down in the ranking. 2018 saw the upwards movement of France (from the $6^{\text {th }}$ to the $5^{\text {th }}$ position), Japan (from the $9^{\text {th }}$ to the $8^{\text {th }}$ ) and Turkey (from the $10^{\text {th }}$ to the $9^{\text {th }}$ ) and the fall of Great Britain (from the $5^{\text {th }}$ to the $6^{\text {th }}$ ) and Germany (from the $8^{\text {th }}$ to the $10^{\text {th }}$ ).

Of the ten countries estimated by the Global Firepower Index to have the greatest military potential, as many as five are located in Europe, namely Russia, Great Britain, France, Germany and Turkey (assuming that the latter counts as a European country). A further four are Asian powers, namely China, India, South Korea and Japan. This exemplifies Zbigniew Brzeziński's theory, according to which the global leaders were the "grand player" (the USA) and nine countries from the Eurasian chessboard. All of them are mentioned in The Grand Chessboard as the key geostrategic players (France, Germany, Russia, China and India) or the geopolitical pivots (South Korea and Turkey).

According to Brzeziński, the geostrategic players are the countries which want to and can use their own power and external influence to shape the geopolitical situation. Their activities are driven by various motivations, including national ambitions, ideological expansion, seeking power or domination, and so on. The geopolitical pivots, in turn, "are the states whose importance is derived not from their power and motivation but rather from their sensitive location, and from the consequences of their potentially vulnerable condition for the behavior of geostrategic players" (Brzeziński, 1997: 41). The data from 2018 shows, however, that South Korea and Turkey increased their respective military potential, thereby going up in the ranking (Turkey from the $10^{\text {th }}$ to the $9^{\text {th }}$ position) or retaining their position (South Korea - the $7^{\text {th }}$ position). The argument by Brzeziński that the importance of South Korea and Turkey is only the outcome of their geographical location and the potential aftermath of their internal instability is therefore disputable, as their increasing military potential is gaining in importance as well.

Great Britain and Japan have also found themselves in the top ten according to the Global Firepower Index, although Brzeziński did not classify them as geostrategic players. Nevertheless, the analysis of his opinion on Great Britain, formulated in late $20^{\text {th }}$ century, shows that it remains valid, as evidenced by the following quote: "Great Britain is not a geostrategic player. It has fewer major options, it entertains no ambitious vision of Europe's future, and its relative decline has also reduced its capacity to play the traditional role of the European balancer. Its ambivalence regarding European unification and its attachment to a waning special relationship with America have made Great Britain increasingly irrelevant insofar as the major choices confronting Europe's future are concerned" (Brzeziński, 1997: 42).

This is how Japan was described in The Grand Chessboard: "As one of the very top economic powers in the world, Japan clearly possesses the potential for the exercise of first-class political power. Yet it does not act on this, eschewing any aspirations for regional domination and preferring instead to operate under American protection. [...] Japan prefers not to become engaged in the politics of the Asian mainland, though at least 
a partial reason for this is the continued hostility of many fellow Asians to any Japanese quest for a regionally preeminent political role. [...] Japan is thus not a geostrategic player, though [is has] obvious potential for quickly becoming one - especially if either China or America were suddenly to alter its current policies" (Brzeziński, 1997: 45).

The above-mentioned change of policies by both the USA and China towards Japan has recently become a reality. The increasingly expansionist policy of China in the region, the new US strategy implemented by President Donald Trump, as well as the growing threat posed by North Korea and Japan's numerous territorial disputes with its neighbors, have all forced Japanese foreign and security policy to evolve. One of the crucial manifestations of this evolution is the expansion of the Japanese security sector and its increased military potential (resulting in Japan's promotion from the $9^{\text {th }}$ to the $8^{\text {th }}$ position in the global ranking). All of this makes Japan an increasingly important player on the Eurasian chessboard.

An alternative methodology for assessing military power has been developed by an expert team from the Powermetric Research Network (Powermetric, 2018), who applied powermetric formulae. They take the following three criteria into account:

a) military expenditure of a country in a given calendar year as stated in The Military Balance statistics published by the International Institute for Strategic Studies;

b) the number of soldiers on active duty as stated in The Military Balance statistics published by the International Institute for Strategic Studies;

c) the territory of the state as stated in the statistics available from the Department of Economic and Social Affairs of the United Nations.

The authors of the study The Power of States, 2017. The International Power Balance in Evolution. A Powermetric Report state that military power is a militarized aspect of general power. This militarization is twofold, as it is manifested both in economic terms, through the share of military expenditure in the country's GDP, and in demographic terms, through the proportion of soldiers on active duty in the general population. "The military burden on GDP and the population can be significant. During peacetime it can range from $1 \%$ to $10 \%$ of GDP and from $0.1 \%$ to $1.5 \%$ or more of population [...] While the former indicator is moderate compared with other states of the world, the latter seems low. During the Cold War, these two indicators were considerably higher, and the end of the Cold War was followed by the economic and demographic demilitarization, a trend which has recently reversed" (Białoskórski, 2017: 58).

The Powermetric Research Network has assessed the military power of the strongest states in 2015-2017 in the following manner:

Table 2

Military power of the top ten strongest states in 2015-2017 in terms of their respective ranking and level of power

\begin{tabular}{||c|l|c|l|c||}
\hline \hline Category/Year & \multicolumn{2}{|c|}{2015} & \multicolumn{2}{c||}{2017} \\
\hline Terms of ranking & \multicolumn{1}{|c|}{ Country } & Level of power & \multicolumn{1}{c||}{ Country } & Level of power \\
\hline I & \multicolumn{1}{|c|}{ II } & III & \multicolumn{1}{c||}{ IV } & V \\
\hline 1 & United States & 226,8 & United States & 231,4 \\
\hline 2 & China & 100,1 & China & 101,6 \\
\hline 3 & Russia & 42,0 & Russia & 41,7 \\
\hline
\end{tabular}




\begin{tabular}{||c|l|c|l|c||}
\hline I & \multicolumn{1}{|c|}{ II } & III & \multicolumn{1}{c|}{ IV } & V \\
\hline 4 & India & 38,3 & India & 41,1 \\
\hline 5 & Saudi Arabia & 35,2 & Saudi Arabia & 28,7 \\
\hline 6 & France & 20,8 & Japan & 21,4 \\
\hline 7 & United Kingdom & 20,1 & France & 21,4 \\
\hline 8 & Brazil & 19,9 & Brazil & 20,4 \\
\hline 9 & Japan & 18,9 & United Kingdom & 19,7 \\
\hline 10 & Rep. of Korea & 17,6 & Rep. of Korea & 18,2 \\
\hline
\end{tabular}

Source: Author's own research on the basis of a range of powermetric reports developed by the Powermetric Research Network, including among others: R. Białoskórski, R. Kobryński, M. Sułek, Potęga państw 2017. Międzynarodowy uklad sit w procesie zmian. Raport potęgometryczny, Warszawa 2017; R. Białoskórski, R. Kobryński, M. Sułek, Potęga państw 2018. Międzynarodowy układ sit w procesie zmian. Raport potęometryczny, Warszawa 2018 (in print).

In the period analyzed, the USA had a huge advantage over the remaining powers, which further increased in 2017. The current military potential of the USA is comparable to those of the next five countries combined. The second global power identified on the basis of the methodology adopted was China, which was way ahead of Russia. US power is double that of China and over five times that of Russia. Apart from the USA (the grand player) and Brazil, the remaining top ten countries are those from the Eurasian chessboard. They witnessed certain shifts of their respective potential and ranking in 2015-2017. Nearly all of them (except for Russia and Saudi Arabia) increased their military potential. France fell from the $6^{\text {th }}$ to the $7^{\text {th }}$ position in the ranking, Great Britain fell from the $7^{\text {th }}$ to the $9^{\text {th }}$, while Japan climbed from the $9^{\text {th }}$ to the $6^{\text {th }}$ position.

The estimates of both the Global Firepower Index and Powermetric Research Network point to the USA as the dominant military power in the world. The USA has a clear advantage over the remaining countries, among which those from the Eurasian chessboard play the essential role, as Zbigniew Brzeziński had anticipated. This is also confirmed by the data on major military spending collected by a specialized website, statista.com.

The calculations by statista.com demonstrate that US military spending in 2017 equaled $35 \%$ of global military expenditure, while in the case of China it was $13 \%$, Saudi Arabia 4\%, Russia 3.8\%, India 3.7\%, France 3.3\%, Great Britain 2.7\%, Japan $2.6 \%$, Germany $2.5 \%$, South Korea $2.3 \%$, Brazil $1.7 \%$, Italy $1.7 \%$, Australia $1.6 \%$, Canada $1.2 \%$, and Turkey $1 \%$. US military spending was thus close to that of the next 8 countries in the ranking combined. All of them (except Brazil) are located on the Eurasian chessboard.

The military power of the USA and some countries on the Eurasian chessboard is also evidenced by data collected by the Stockholm International Peace Research Institute (SIPRI) on changes in military expenditure in different parts of the world, nuclear arsenal and the world's largest arms exporters and importers. Concerning the changes in military expenditure in different parts of the world (2016-2017), a significant decrease can be observed in some countries, for instance in North Africa and Eastern Europe. On the other hand, a considerable rise in military expenditure was noted in South America, Central and South Asia, East Asia, Central Europe and Western Europe - that is, in parts of the Eurasian chessboard, among other locations. 
Graph 1. The 15 countries with the highest military spending worldwide in 2017 (in billion U.S. dollars)

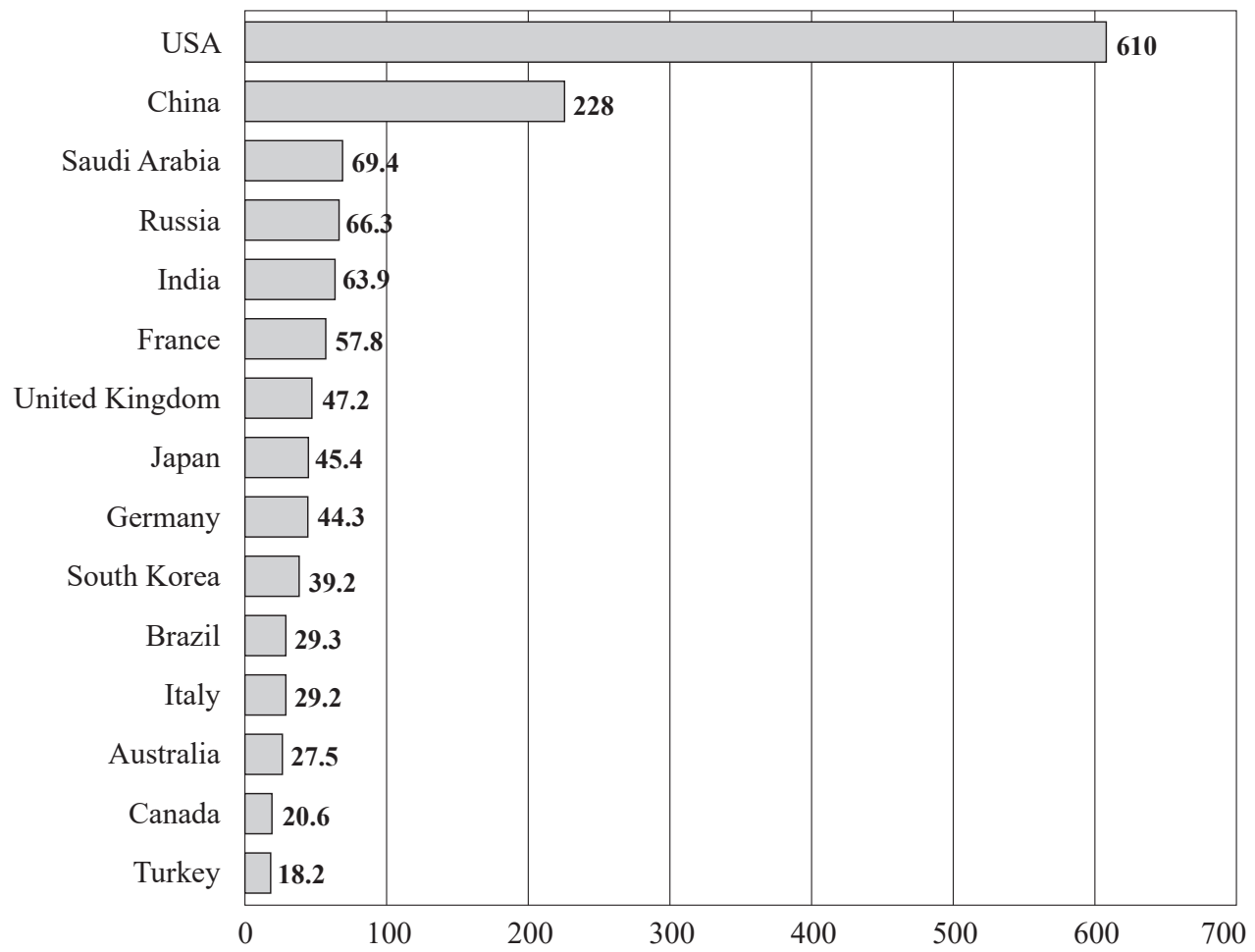

Source: TITLE, https://www.statista.com/statistics/262742/countries-with-the-highest-military-spending.

Graph 2. Changes in military expenditure by region (2016-2017)

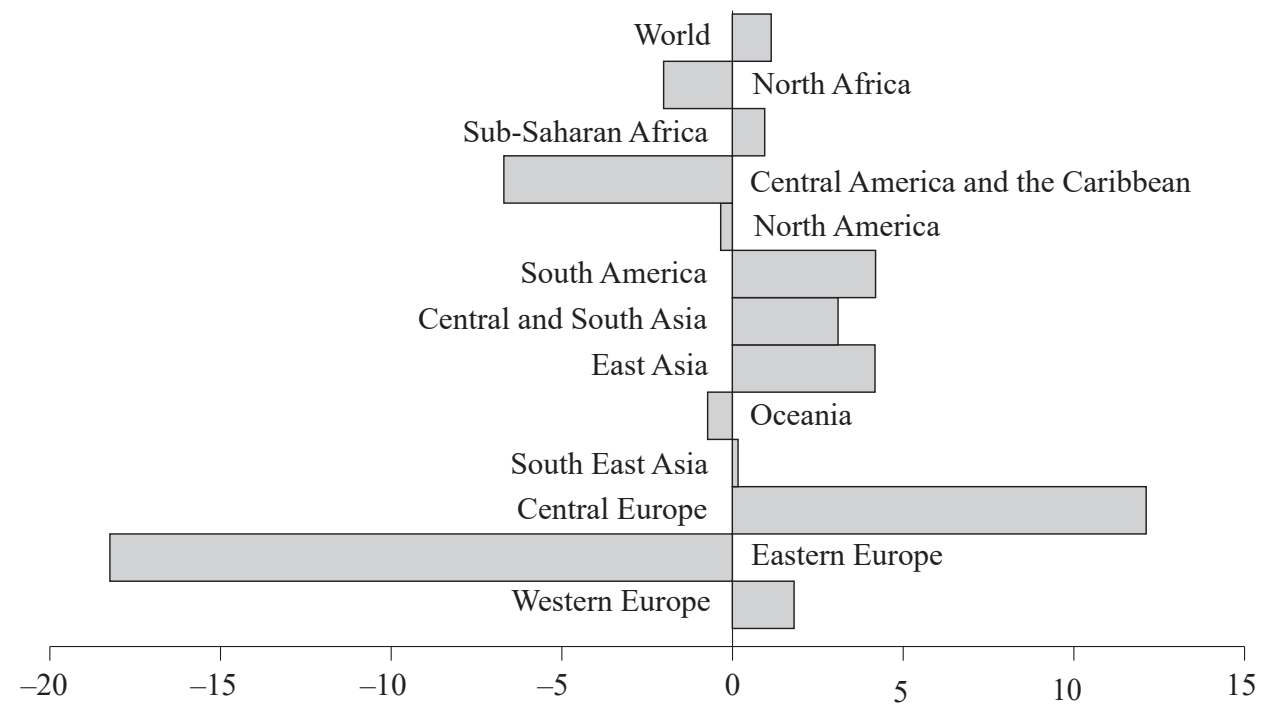

Source: SIPRI Yearbook 2018, Armaments, Disarmament and International Security (2018), Oxford. 
The USA and the countries of the Eurasian chessboard are also global monopolists in the field of nuclear weapons. The so-called Nuclear Club has nine members, with the following potential:

World nuclear forces (January 2018)

\begin{tabular}{||l|c|c|c|c||}
\hline \multicolumn{1}{|c|}{ Country } & Deployed Warheads* & Other warheads** & Total 2018 & Total 2017 \\
USA & 1.750 & 4.700 & 6.450 & 6.800 \\
Russia & 1.600 & 5.250 & 6.850 & 7.000 \\
UK & 120 & 95 & 215 & 215 \\
France & 280 & 20 & 300 & 300 \\
China &. & 280 & 280 & 270 \\
India &. & $130-140$ & $130-140$ & $120-130$ \\
Pakistan &. & $140-150$ & $140-150$ & $130-140$ \\
Israel &. & 80 & 80 & 80 \\
North Korea &.. &.. & $(10-20)$ & $(10-20)$ \\
Total & 3.750 & 10.715 & 14.465 & 14.935 \\
\hline
\end{tabular}

* 'Deployed warheads' refers to warheads placed on missiles or located on bases with operational forces.

** 'Other warheads' refers to stored or reserve warheads and retired warheads awaiting dismantlement.

Source: SIPRI Yearbook 2018, Armaments, Disarmament and International Security (2018), Oxford.

Total figures include the highest estimate when a range is given. Figures for North Korea are uncertain and are not included in total figures. All estimates are approximate.

Yet another example is provided by the SIPRI data on the largest arms exporters and importers in the world. The list of the top ten exporters includes the USA and the countries from the Eurasian chessboard only. Concerning importers, this group also included Egypt, Australia, Algeria and Indonesia in 2013-2017.

The main exporters and importers of major weapons (2013-2017)

\begin{tabular}{||l|c|l|c||}
\hline \multicolumn{1}{|c|}{ Exporter } & Global share (\%) & \multicolumn{1}{c|}{ Importer } & Global share (\%) \\
\hline 1. USA & 34.0 & 1. India & 12.0 \\
\hline 2. Russia & 22.0 & 2. Saudi Arabia & 10.0 \\
\hline 3. France & 6.7 & 3. Egypt & 4.5 \\
\hline 4. Germany & 5.8 & 4. UAE & 4.4 \\
\hline 5. China & 5.7 & 5. China & 4.0 \\
\hline 6. UK & 4.8 & 6. Australia & 3.8 \\
\hline 7. Spain & 2.9 & 7. Algeria & 3.7 \\
\hline 8. Israel & 2.9 & 8. Iraq & 3.4 \\
\hline 9. Italy & 2.5 & 9. Pakistan & 2.8 \\
\hline 10. Netherlands & 2.1 & 10. Indonesia & 2.8 \\
\hline
\end{tabular}

Source: SIPRI Yearbook 2018, Armaments, Disarmament and International Security (2018), Oxford.

The analysis of reports on the military potential of different states published by such academic and analytical centers as the Global Firepower Index, Powermetric Research Network or SIPRI Yearbook Armaments, Disarmament and International Security, to 
name just a few, demonstrates that the USA continues its military domination in the world. The advantage of the USA in the different categories examined is usually considerable. The conviction which Zbigniew Brzeziński had concerning the particular importance of the Eurasian chessboard and the fact that almost every global military power is located there remains valid. One can therefore speak about the military status quo on the Eurasian chessboard.

\section{Sebastian WOJCIECHOWSKI}

Editor in chief

We are presenting the eleventh issue of the Strategic Review, this time prepared mainly in English. This will hold true for the subsequent issues of our journal, which results from our intention to make the journal and the matters it discusses even more international.

\section{REFERENCES}

Białoskórski R., Kobryński R., Sułek M. (2017), Potęga państw 2017. Międzynarodowy układ sit w procesie zmian. Raport potęgometryczny, Warszawa.

Białoskórski R., Kobryński R., Sułek M. (2018), Potęga państw 2018. Międzynarodowy układ sit $w$ procesie zmian. Raport potęgometryczny, Warszawa.

Brzeziński Z. (1997), The Grand Chessboard, Basic Books, New York.

Łoś R. (2017), Soft power we wspótczesnych stosunkach międzynarodowych, Łódź.

Military Strength Ranking 2018, Global Firepower Index, https://www.globalfirepower.com/countries-listing.asp (1.07.2018).

Powermetric Research Network, www.prnet.org.pl (29.05.2018).

SIPRI Yearbook (2017), Armaments, Disarmament and International Security, Oxford.

SIPRI Yearbook (2018), Armaments, Disarmament and International Security, Oxford.

Sułek M. (2013), Potęga państw. Modele i zastosowania, Warszawa.

"The Military Balance" - International Institute for Strategic Studies, https://www.iiss.org/publications/the-military-balance/the-military-balance-2018 (4.07.2018).

Wyspiański S. (2012), The Wedding, London. 